\title{
Tackling Post-Operative Cutaneous Scarring with Autologous Cell Therapy
}

\author{
Denis E. Solomon \\ 9B Somerville Road, Wigan, England (UK) \\ Email: denissolomon@yahoo.com
}

How to cite this paper: Solomon, D.E. (2017) Tackling Post-Operative Cutaneous Scarring with Autologous Cell Therapy. Open Journal of Regenerative Medicine, 6, 27-33.

https://doi.org/10.4236/ojrm.2017.63003

Received: February 28, 2017

Accepted: September 12, 2017

Published: September 15, 2017

Copyright $\odot 2017$ by author and Scientific Research Publishing Inc. This work is licensed under the Creative Commons Attribution International License (CC BY 4.0).

http://creativecommons.org/licenses/by/4.0/

\section{(c) (i) Open Access}

\begin{abstract}
Regenerative medicine has brought about refreshing new thinking about age old problems. However, some problems remain mostly untouched and are not being addressed. A point in question is the track of scar tissue left behind post-operatively, which reveals the surgeon's line of invasive incision. This confers on the patient an adverse psychological reminder and burden for the rest of his/her life. Most patients cannot afford corrective plastic surgery to ameliorate this skin defect. This paper seeks to ask whether biomedical scientists could play a role in arriving at a more pleasing cosmetic result, using a simple cell culture procedure of isolating un-manipulated autologous primary epidermal and dermal cells from a small skin tissue segment in close proximity to the surgeon's incision line.
\end{abstract}

\section{Keywords}

Cutaneous Scarring, Post-Operative, Epidermal Rosettes, Dermal Fibroblasts, Autologous Cell Therapy, Wound Healing

\section{Introduction}

If one uses the key words "post-operative cutaneous scarring" and conducts a search using the PubMed search engine, you receive notice of only sixty-seven past publications in this field. As with most collations, some publications are not relevant. The last publications were in 2015. The second paper in the given list, also a 2015 publication, by van den Broek L. J. et al. [1] states that: 1) wound healing is studied at one point in time, even though the process is dynamic and takes months, even years; 2) any results from animal models are difficult to extrapolate to the human condition because of differences in scar tissue, physiology and immunology.

However, from animal studies and cytotoxic tests using murine fibroblasts, 
surgical sutures, foreign bodies which trigger a localised immune response (Rosique R.G. et al., 2015 [2]; Robson MC and Barbul A., 2006 [3]), have been approved.

\section{Multicellular Rosettes}

This author has described epidermal brown rosettes as natural, living intra-epidermal micro patterns within the human epidermis [4]. Congruent with this finding was the later review by Harding et al. (2014) [5] and references therein, which discussed the wide role played by multicellular rosettes in morphogenesis of diverse organ systems describing them as polarized, transient epithelial structures which sometimes recapitulate the form of the adult organ. They noted their occurrence in developmental contexts such as in the zebrafish lateral line primordium, the vertebrate pancreas, the Drosophila epithelium and retina, in the adult neural stem cell niche and in stem cell populations. These rosettes were defined as multicellular structures in which five or more cells interface at a central point and their remodelling contributes to the formation of a functional organ. Multicellular rosettes are, in their words, "a broadly utilized mechanism during morphogenesis"; however they noted that the extracellular matrix cues that trigger their formation are not well understood. In the regeneration of damaged skin tissue, it could be expected that a biological recapitulation of this theme might occur laying bare a congruency with the previously mentioned human skin epidermal rosettes.

\section{The Dermis}

It is known that the dermis consists of primary fibroblasts (Hastings and Shapiro, 2016) [6]. This author has demonstrated, albeit in an in vitro setting, that un-manipulated primary $\left(\mathrm{P}_{0}\right)$ human dermal reticular fibroblasts retain their spatial configuration and their signature packing arrangement at an angle to the vertical [7]. Whether these cells have a short- or long-term memory has not been determined. However, it is well known that T-cells retain a bank of "long-lived memory-cells" (Macallan et al., 2017) [8] as a defence against future pathogen challenge. Human skin is protected by four functionally and phenotypically discrete populations of resident and recirculating memory T-cells (Watanabe et al., 2015) [9]. Also, the dermis does not only contain fibroblasts. There are mast cells, microvascular endothelial cells, dendritic cells, multipotent mesenchymal stromal cells (MSCs), Merkel cells just to name a few other cell residents.

\section{Reasons for a Scientific Hands-On Involvement}

Any proposal of autologous cell therapy, suggesting the collection of a skin tissue segment immediately post-surgery with the intention of culturing the patient's own cells envisages the handing over of the skin tissue segment to specialist biomedical scientists. Secondly, deploying any live cells to wounds closed by using sutures/staples/tape post-operatively would require experienced hands. A tech- 
nique must be perfected, which will require a joint effort between medical personnel and biomedical scientists.

No stem cell use is initially being put forward because its use would necessarily need the absolute knowledge of the "threshold quantity" of cells which would not evoke an eruption of tissue inflammation. Newspaper reports have spoken of patients travelling abroad (outside of the UK) to receive stem cell injections for various ailments, only to find they needed to rush back to the UK for urgent hospital treatment due to unforeseen tissue inflammation (also see [10] [11]).

\section{Concept}

The autologous cell therapy being proposed will involve both epidermal and dermal cells being applied in stepwise fashion, provided a skin tissue segment and a sample of the patient's blood, for preparation of serum/plasma are obtained post-surgery. The donor site of the small skin tissue segment must be as close to the incision line as possible. To state the obvious, this will insure the later laboratory harvest of 'local' populations of both epidermal and dermal cells.

There will be no manipulation of said cells in culture since only primary $\left(\mathrm{P}_{0}\right)$ cells will be used. A skin segment will be broken down into its cellular compartments with a singular enzymatic use to achieve separation of the epidermis from the dermis. This author has described full details of these methods in previous publications [4] [12].

In a cell culture laboratory, the disassembling epidermis resembles a stack of coins, whose structure is being dismantled on a vertical axis [4]. Interestingly, within the chloroplast of a leaf, the thylakoids in a granum, also strongly and distinctly resemble a small stack of coins. This displays a degree of commonality in Nature's structural blueprint [13]. Research studies have been concentrated on expansion of keratinocytes in culture, and not the epidermal rosettes for application to wound beds, the latest publication being Martin et al. (2017) [14], using compressed collagen and microcarriers. They commented on the loss of cells in an applied suspension due to a lack of adhesion to the wound bed. This point was actively considered and specifically addressed in the described methodology. Plasma properties are given below and there is a correlation with oral surgery where fibroblast-induced repair, using plasma enriched with growth factors (PRGF-Endoret), was found to stimulate the proliferation and migration of primary keratinocytes and conjunctival fibroblasts [15].

\section{Consideration of Wound Exudates}

It is recognized that in undamaged skin, plasma bathes the interstices of skin tissue. In damaged skin, serum factors are released. Therefore, all cells will be isolated and immersed in the patient's plasma. Of primary importance, before any cell transplantation is undertaken, a culture of the wound's drainage fluid or exudate should be conducted to determine if there is pathogen growth (Candau-Alvarez A. et al., 2015) [16]. Concomitantly, it might be informing, to draw 
a parallel with burn bound exudates, and test for the skin-specific chemokine CCL27, with regard to an indication of scar formation (Widgerow $\mathrm{AD}$ et al., 2015) [17].

\section{Methodology}

\subsection{Epidermis}

The collected skin segment will be taken to a tissue culture laboratory, rinsed, subcutaneous fat trimmed off and cut into small pieces. They are upturned (epidermis-side down) in a small pool of Dispase [5] and put into an incubator at $37^{\circ} \mathrm{C}$ for overnight incubation. The next morning, in the flow cabinet, the epidermis from each piece of skin tissue will be peeled off using a pair of forceps, and immersed in DPBS. The epidermis will disassemble on a vertical axis into the previously described epidermal rosettes. No attempt will be made to identify "upright" or "inverted" rosettes. Some inverted rosettes will be basal layer rosettes, containing "live" melanocytes and epidermal-melanin units [5] to aid pigmentation restoration. They will all be transferred, after pooling, to a plastic centrifuge tube containing an aliquot of the patient's plasma. Using a pipette aspirator, they will be drawn up into the pipette and are now ready for transplantation directly onto the wound bed.

The epidermal rosettes described above will be subcutaneously transplanted in toto. This has not been attempted in any study thus far and will provide hopefully, an accelerated means of restoring the epithelial barrier. If a delay is sought, for example, to wait until wound exudate has ceased or cultured, it is known that the epidermal rosettes do maintain their structural integrity in vitro as was clearly observed when a co-culture of epidermal rosettes, dermal microvascular endothelial cells and dermal fibroblasts was attempted [12]. They do not shed their load of cells onto a plastic surface; only onto a cell matrix [4]. In this instance, they will be pipetted into a plastic culture flask topped up with an aliquot of plasma (to allow for evaporation loss) and stored in the incubator.

\subsection{Dermis}

After the epidermis is removed, the dermis will be rinsed, as described previously [4] [12] and each tissue piece, scraped with a scalpel with attached blade. Scrapings, consisting of both papillary and reticular fibroblasts will be shaken off into a plastic centrifuge tube containing an aliquot of the patient's plasma. These dermal cells, after pooling, are now ready for subcutaneous transplantation. Further scrapings, deeper into the dermis will yield reticular fibroblasts and other resident dermal phenotypically discrete populations.

Subsequently, there are two ways to proceed. If a delay is sought, these cells may be pipetted into a culture flask, topped up with an aliquot of plasma and incubated. It is known that confluence occurs in 9 days. For a shorter time period to confluence, the fibroblasts can be pipetted onto a pre-prepared dermal fibroblast matrix contained in a culture flask. 
Care will be taken to aid the healing process while not overly interfering by adding a cellular overload. A cell pellet of dermal fibroblasts was considered, and then rejected, through fear of creating an in situ inflammatory site. There will be no discomfort experienced by the patient. Of course, results will need to be evaluated to determine whether the procedure needs tweaking, meaning that the treatment interval needs to be extended. However, this would now necessarily involve using $\mathrm{P}_{1}$ dermal cells, obtained by using $5 \mathrm{mM}$ EDTA/DPBS ( $\mathrm{pH} 7.4$ ) as previously described [12] (Ethylene diamine tetra-acetic acid/Dulbecco's phosphate- buffered saline) or using a cell scraper which will yield a dermal fibroblast cell cluster population plus fragments of their extracellular matrix (ECM). Great care will have to be taken in the choice of a plastic pipette with a sufficiently wide tip to insure that the structural integrity of the cell clusters are maintained.

\section{Conclusion}

A pilot study will determine the efficacy of the described methodology and compare the results with less complicated wounds healed by "primary intention" (Summers and Siegle, 1993) [18] using sutures, staples or tape. Finally, lengths of sutures used to close a wound will get exposed to primary epidermal and dermal cells. It will be of note whether the inflammatory response is dampened (see Georgiev-Hristov T. et al., 2012) [19]. Another use for this technique could be in the healing of the donor site after a skin graft is obtained. If the obtained skin graft was slightly larger than necessary, a small tissue segment could be handed over for the isolation of autologous cells as detailed above.

\section{Notes}

1) An off-the-cuff idea which might find fertile ground with my academic peers. Since the dermal fibroblasts will be lying in the patient's own plasma awaiting transplantation, the plasma will become "conditioned" by their secretions (ECM components and fibroblast growth factors). Table I [12] lists some of those secretions. Also, human blood plasma is more than an ordinary fluid; it exhibits viscoelastic behaviour (see Brust M. et al., 2013) [20]. Hence, consideration might be given to the use of the dermal fibroblast conditioned plasma as a means of "nutritious irrigation" of the wound site.

2) It is to be hoped that the methodology described herein will lead to a more aesthetically pleasing result than the skin blemish obtained by micrografting [21].

\section{Conflicts of Interest}

None since this is a proposed medical treatment. However, there are granted UK patents to the author with respect to: 1) the epidermal basal layer rosettes, but they are not being specifically isolated for identification and study here; 2 ) isolation of human dermal papillary and/or reticular fibroblasts by mechanical abrasion (scraping with a scalpel and attached blade). 


\section{Acknowledgements}

The author expresses his continued gratitude to the University of Miami School of Medicine, Miami, FL and to Emeritus Professors, J.K. Raines, T. Malinin and sadly, the late S.L. Hsia for offered facilities during the Summer of 2001. B.E. Buck MD and D. Eton MD are also honourably mentioned.

\section{References}

[1] van den Broek, L.J., van der Veer, W.M., de Jong, E.H., Gibbs, S. and Niessen, F.B. (2015) Suppressed Inflammatory Gene Expression during Human Hypertrophic Scar Compared to Normotrophic Scar Formation. Experimental Dermatology, 24, 623-629. https://doi.org/10.1111/exd.12739

[2] Rosique, R.G., Rosique, M.J. and Farina Jr., J.A. (2015) Curbing Inflammation in Skin Wound Healing: A Review. International Journal of Inflammation, 2015, Article ID: 316235. https://doi.org/10.1155/2015/316235

[3] Robson, M.C. and Barbul, A. (2006) Guidelines for the Best Care of Chronic Wounds. Wound Repair and Regeneration, 14, 647-648. https://doi.org/10.1111/j.1524-475X.2006.00173.x

[4] Solomon, Denis E. (2012) Mimicry of a Natural, Living Intra-Epidermal Micro Pattern Used in Guided Tissue Regeneration of the Human Epidermis. Journal of Developmental Biology and Tissue Engineering, 4, 1-7. www.academicjournals.org/journal/JDBTE/articles

[5] Harding, M.J., McGraw, H.F. and Nechiporuk, A. (2014) The Roles and Regulation of Multicellular Rosette Structures during Morphogenesis. Development, 141, 2549-2558. https://doi.org/10.1242/dev.101444

[6] Hastings, J.D. and Shapiro, S. (2016) Healing Wounds under Mechanical Stress: A Case Example. International Journal of Clinical Medicine, 7, 120-126. https://doi.org/10.4236/ijcm.2016.72013

[7] Solomon, D.E. (2013) Human Dermal Reticular Fibroblasts at Confluence Display a Signature Micro Pattern In Vitro. Open Journal of Regenerative Medicine, 2, 99-105. https://doi.org/10.4236/ojrm.2013.24014

[8] Macallan, D.C., Borghans, J.A.M. and Asquith, B. (2017) Human T Cell Memory: A Dynamic View. Vaccines (Basel), 5, 1-12. https://doi.org/10.3390/vaccines5010005

[9] Watanabe, R., Gehad, A., Yang, C., Campbell, L., Teague, J.E., Schlapbach, C., Elco, C., Huang, V., Matos, T.R., Kupper, T.S., and Clark, R.A. (2015) Human Skin Is Protected by Four Functionally and Phenotypically Discrete Populations of Resident and Recirculating Memory T Cells. Science Translational Medicine, 7, 279 ra39. https://doi.org/10.1126/scitranslmed.3010302

[10] Canadian Cancer Society (2017) Side Effects of Stem Cell Transplant. http://www.cancer.ca/en/cancer-information/diagnosis-and-treatment/stem-cell-tra nsplant/side-effects-of-stem-cell-transplant

[11] Abbott, A. (2014) Doubts on Heart Stem-Cell Therapy. Nature News Comment, 509, 15-16. https://doi.org/10.1038/509015a

[12] Solomon, D.E. (2002) An In Vitro Examination of an Extracellular Matrix Scaffold for Use in Wound Healing. International Journal of Experimental Pathology, 83, 209-216. https://doi.org/10.1046/j.1365-2613.2002.00238.x

[13] Solomon, D.E. (2016) Skin Cell Research in Miami. Booklet at Amazon. CreateSpace, Charleston, South Carolina, USA. https://www.amazon.com/books

[14] Martin, Y.H., Jubin, K., Smalley, S., Wong, J.P., Brown, R.A. and Metcalfe, A.D. 
(2017) A Novel System for Expansion and Delivery of Human Keratinocytes for the Treatment of Severe Cutaneous Injuries Using Microcarriers and Compressed Collagen. Journal of Tissue Engineering and Regenerative Medicine. [Epub Ahead of Print] https://doi.org/10.1002/term.2220

[15] Anitua, E., Sanchez, M., Merayo-Lloves, J., De la Fuente, M., Muruzabal, F. and Orive, G. (2011) Plasma Rich in Growth Factors (PRGF-Endoret) Stimulates Proliferation and Migration of Primary Keratocytes and Conjunctival Fibroblasts and Inhibits and Reverts TGF-Beta1-Induced Myodifferentiation. Investigative Ophthalmology \& Visual Science, 52, 6066-6073. https://doi.org/10.1167/iovs.11-7302

[16] Candau-Alvarez, A., Linares-Sicilia, M.J., Dean-Ferrer, A. and Pérez-Navero, J.L. (2015) Role of Culture of Postoperative Drainage Fluid in the Prediction of Infection of the Surgical Site after Major Oncological Operations of the Head and Neck. British Journal of Oral and Maxillofacial Surgery, 53, 200-203. https://doi.org/10.1016/j.bjoms.2014.11.005

[17] Widgerow, A.D., King, K., Tussardi, L.T., Banyard, D.A., Chiang, R., Awad, A., Afzel, H., Bhatnager, S., Melkumyan, S., Wirth, G. and Evans, G.R.D. (2015) The Burn Wound Exudate-An Under-Utilized Resource. Burns, 41, 11-17. https://doi.org/10.1016/j.burns.2014.06.002

[18] Summers, B.K. and Siegle, R.J. (1993) Facial Cutaneous Reconstructive Surgery: General Aesthetic Principles. Journal of the American Academy of Dermatology, 29, Pt. 1: 669-681. https://doi.org/10.1016/0190-9622(93)70230-Q

[19] Georgiev-Hristov, T., García-Arranz, M., García-Gómez, I., García-Cabezas, M.A., Trébol, J., Vega-Clemente, L., Díaz-Agero, P. and García-Olmo, D. (2012) Sutures Enriched with adipose-Derived Stem Cells Decrease the Local Acute Inflammation after Tracheal Anastomosis in a Murine Model. European Journal of Cardio-Thoracic Surgery, 42, e40-e47. https://doi.org/10.1093/ejcts/ezs357

[20] Brust, M., Schaefer, C., Doerr, R., Pan, L., Garcia, M., Arratia, P.E. and Wagner, C. (2013) Rheology of Human Blood Plasma: Viscoelastic versus Newtonian Behavior. Physical Review Letters, 110, Article ID: 078305. https://doi.org/10.1103/PhysRevLett.110.078305

[21] Smith Jr., D.J. (2014) Achieving Efficient Wound Closure with Autologous Skin. Today's Wound Clinic, 8, January/February, 23-24.

http://www.todayswoundclinic.com/articles/achieving-efficient-wound-closure-aut ologous-skin?page $=2$

Submit or recommend next manuscript to SCIRP and we will provide best service for you:

Accepting pre-submission inquiries through Email, Facebook, LinkedIn, Twitter, etc. A wide selection of journals (inclusive of 9 subjects, more than 200 journals)

Providing 24-hour high-quality service

User-friendly online submission system

Fair and swift peer-review system

Efficient typesetting and proofreading procedure

Display of the result of downloads and visits, as well as the number of cited articles

Maximum dissemination of your research work

Submit your manuscript at: http://papersubmission.scirp.org/

Or contact ojrm@scirp.org 